研究論文：論文

\title{
IT コンサルティング顧客満足度向上への影響要因と制御
}

\author{
高い顧客満足を得られる商品開発に関する研究（3）
}

\author{
石田 厚子*, 湊淳*, 小澤哲*
}

*茨城大学大学院

\section{CONTROL OF INFLUENTIAL ELEMENTS TO CUSTOMER DELIGHT OF IT CONSULTING}

\author{
HIGHLY CUSTOMER-SATISFIED PRODUCTS'DEVELOPMENT (3) \\ Atsuko ISHIDA*, Atsushi MINATO*, and Satoru OZAWA* \\ *Ibaraki University,4-12-1,Nakanarusawa,Hitachi-shi,316-8511 Japan
}

\begin{abstract}
Recently, customers want not only products themselves but also know how and service annexed to them. In this paper, we made a study of 'consulting service', especially 'information technology (IT) consulting'. We analyzed a relation between a sensual quality of service and a level of customer delight, and got a result that correlation was influenced by communications between clients and consultants. At first, we defined structure and quality of consulting service, and made a model of customer delight with quality of service. Next, we analyzed customers' responses to questions about real IT consulting cases, and introduced influential elements to customer delight and ways of improving them. Further, we noticed a fact that these elements were affected by a relationship between clients and consultants. At last, we suggested that good communications were essential to customer delight.

Keyword: Communications; Expected Quality; Sensual Quality
\end{abstract}

\section{1.はじめに}

近年, 新しい技術が新たな商品と市場を生み出す傾向が強 くなっている。さらに, 顧客が商品の価值に対して払われる 対価は，モノ自体に対するものよりノウハウやサービスに対 してより多くなる傾向にある[1]。

筆者らは, 主として最新の技術を活用した新しい商品／ビ ジネスモデルを対象にして，その発想，開発，提供から高い 顧客満足度を得るまでのプロセスに従い, 顧客満足度向上施 策の研究を進めてきた[2][3]。その中では, 顧客が商品を購 入する前に予測する品質と購入した結果得られる実際の品質 のギャップを「寒感品質」とし，それが顧客満足度を表して いる，としてきた。しかし，顧客にとって価値の不明確な商 品の場合は, 実感品質と顧客満足度の関係は単純ではない, という懸念がある[4]。そこで，サービス主体の商品の代表 的なものとして, 情報システム構築に関わる業務改革と情報 技術（IT）のコンサルティング（以降 IT コンサルティングと 称する）を取り上げ, 顧客の実感する品質と顧客満足度の関 係を明らかにし，それに基づいて，顧客満足度向上の方策を 探ることとした。

まず, これまでの研究から, 商品, 品質, 顧客満足度のモ デルを確認し，それを前提に， IT コンサルティングという商 品の構成要素と品質の定義を行った。次に, その顧客満足度 調査結果から実感品質と顧客満足度の相関を分析し, 顧客満 足度に影響する要因を導いた。最後に, 実感する品質を制御
することにより顧客満足度を向上させることを可能にするた めの条件を明らかにした。

結果として, 顧客（IT コンサルティングを受ける人）と企 業（IT コンサルタント）の間の関係が, 実感品質と顧客満足 度の相関に影響することが得られた。それにより, 顧客満足 度向上のためには, より品質のよい商品（IT コンサルティン グ）を提供して実感品質を高めるだけでなく, 顧客とのコミ ユニケーションを十分にとることにより, 害感品質が顧客满 足度に結びつくようにする必要があることが明確になった。

\section{2. 背景}

\section{1 商品の捉え方}

従来, 商品は, 形のあるもの, 寸なわちハードウエアが中 心であり，製品と同義に扱われることが多かった。近年，八 ードウエアだけでなく, それを動かすノウハウ（ソフトウエ ア），それがうまく動くための支援（サービス）も含めたもの から顧客は価值を得ることができる, と考えられるようにな った。これらを総合的に捉えるものとして「ソリューション」 という言葉がコンピュータメーカ, 情報サービス企業を中心に 盛んに使われるようになった。2000 年 9 月に, (社) 日本電子 工業振興協会 (現 (社) 電子情報技術産業協会) ソリューショ ンビジネス委員会は,ソリューションを「顧客の経営課題を, IT と付加サービスを通じて解決するビジネス技法」と定義し, IT の構成要素をノウハウとキープロダクトとした [5]。我々は, 
付加サービスを, (1)業務分析・システム分析, (2)情報システム 構築, (3)教育・トレーニング, (4)情報システム運用, (5)IT・ビ ジネス・マネジメント， (6)製品サポート，に分けて考えること とした（図 1)。ハードウエア製品（キープロダクト）のみの 商品があるように, パッケージ・ソフトウエアのようなノウハ ウのみの商品, 清掃代行のようなサービスのみの商品もある。 本論文では, サービスの要素が強いがノウハウの要素も含まれ る IT コンサルティングを, 新しいタイプの商品を代表するも のとして取り上げることにした。

\begin{tabular}{|c|c|c|c|c|c|}
\hline \multirow{2}{*}{\multicolumn{2}{|c|}{ 齐ウ }} & \multicolumn{2}{|c|}{ ソリューション } & \multirow{2}{*}{\multicolumn{2}{|c|}{ キープロダクト }} \\
\hline & & \multicolumn{2}{|c|}{$4 \stackrel{4}{4}$} & & \\
\hline \multicolumn{4}{|c|}{ 付加サービス } & \multicolumn{2}{|l|}{ 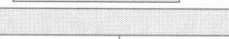 } \\
\hline $\begin{array}{l}\text { 業務分析 } \\
\text { 机ム分析 }\end{array}$ & $\begin{array}{l}\text { 情報シス } \\
\text { 構絯 }\end{array}$ & $\begin{array}{l}\text { 教育. } \\
\text { トレンシグ }\end{array}$ & $\begin{array}{l}\text { 情報引ノステ } \\
\text { 運用 }\end{array}$ & $\begin{array}{l}\text { IT-ビジス } \\
\text { マ衫ジ， }\end{array}$ & $\begin{array}{l}\text { 製品 } \\
+\because ホ ⿰-卜 ~\end{array}$ \\
\hline $\begin{array}{l}\text { 最番解を } \\
\text { アドィイス } \\
\text { するサービス }\end{array}$ & $\begin{array}{l}\text { 情報システム } \\
\text { 構築を支援する } \\
\text { サービス }\end{array}$ & $\begin{array}{l}\text { 教育. } \\
\text { トレーニング } \\
\text { を行うサービス }\end{array}$ & 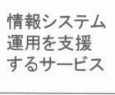 & 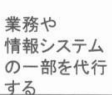 & $\begin{array}{l}\text { 製品活用を } \\
\text { 支援する } \\
\text { サービス }\end{array}$ \\
\hline 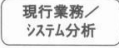 & $\mid \begin{array}{c}\text { システムインテデ } \\
\text { レーション }\end{array}$ & ト数育・゙ダ & 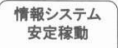 & ASP & $\begin{array}{c}\text { •フㅏㅗ } \\
\text { サポート }\end{array}$ \\
\hline \multirow[t]{3}{*}{ 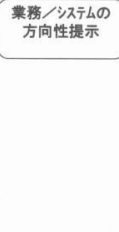 } & シスデム触關 & & 適用支擐 & 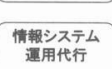 & 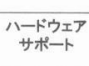 \\
\hline & 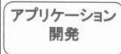 & & $\begin{array}{c}\text { アプリケーション } \\
\text { サポート }\end{array}$ & 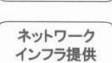 & 橦入支援 \\
\hline & & & & 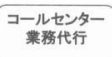 & \\
\hline
\end{tabular}

図 1 ソリューションの概念による商品の定義

\section{2 顧客満足度の捉え方}

通常, 商品の顧客満足度は, 顧客がその商品に抱く期待と 実際にそれを使った結果の差であると言われている[6]。ま た, 同様なことが, 日本経営品質賞の経営品質アセスメント基 準書で,「顧客満足とは, 顧客に期待以上の価值が提供された ときの顧客の心理的状況をいい, 顧客不満足とは, 顧客に期待 より低い価值しか提供されなかったときの顧客の心理的状況 をいう」[7]と表現されている。筆者らは,これらの考え方か ら顧客満足を定量的に捉え，コントロールするためのモデル を提案した[3]（図 2)。ここでは，顧客の心理的要因を含ま ない「商品自体の品質」, 商品を実際に利用する前にその品質 を予測した結果である「予測品質」, 両者のギャップを表す「実 感品質」を導入している。「予測品質」は, 企業が提供する商 品に関する情報の, 顧客による捉え方を表すものであり, そ れに対して顧客の感性が影響することが確かめられている [3]。「実感品質」は, 購入して使用した後の商品自体の品質 と予測品質のギャップを表しており, 顧客満足度と関連して いる。

本モデルの顧客満足度は, customer satisfaction（顧客要 求達成, 要求充足) ではなく, customer delight, すなわち, 顧客を喜ばすことである[8]。本論文で我々が目標としてい るのは, customer delight $の$ 実現である。

我々のこれまでの研究では, 赛感品質はほぼ顧客満足度に 対応するものとして捉えていた。しかし，品質が複数の構成 要素を持っていて, 各々が別々の環境条件に影響される場合 は, 実感品質と顧客満足度の関係は単純ばないと考えられ る。とくに, IT コンサルティングのようなサービス主体の商
品の場合は，八ードウエア主体の商品と比較して，実感品質 と顧客満足度の相関に影響を与える環境条件が多く存在する のではないかと予想される。本論文は，この点を明らかにす ることを目的の一つとしている。

\begin{tabular}{|c|c|}
\hline & $\begin{array}{l}\text { 実感品質 } \\
\quad \Leftrightarrow \quad \text { 顧客満足度 }\end{array}$ \\
\hline & $\begin{array}{c}\text { 導入意思決定必要条件 } \\
\text { (導入の際はプラス }\end{array}$ \\
\hline
\end{tabular}

図 2 商品の品質と顧客満足度の関係モデル（[3]より）

3. IT コンサルティングとは

3. 1 IT コンサルティングの構成要素

本論文では, サービス主体の商品の中でも, その範囲の広さ, 必要とされるスキルの質・量の多様さで大きな価値を提供でき るものとして注目されている, IT コンサルティングを取り上 げる。ここでは, IT コンサルティングを, プロセス・コンサ ルティングとコンテンツ・コンサルティングの 2 種類の形態と して捉え (図 3), 通常の実施形態は, これらの間のどこかに 位置付けられるものと考える。

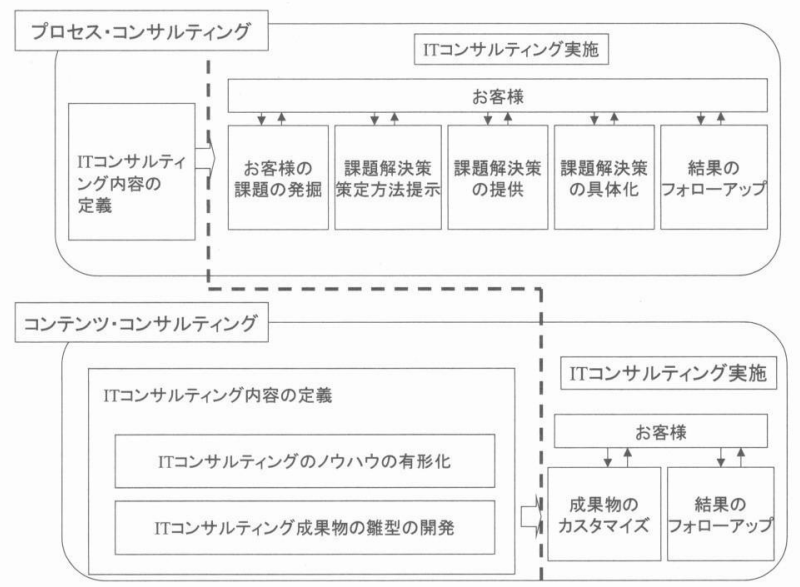

図 3 IT コンサルティングの実施形態

(1) プロセス・コンサルティング

IT コンサルティングを実施することにより結果を作り上げ ていくコンサルティング形態。コンサルティングのプロセスと それを実施する IT コンサルタントのスキル, 顧客の参画の度 合いにより結果の良否が左右される傾向がある。ソリューショ ンの観点からすると, サービスの要素が大半を占める商品であ る。

(2) コンテンツ・コンサルティング

あらかじめ最終結果の㵶型を用意しておき, それを顧客に合 わせてカスタマイズすることにより最終結果を作り上げるコ ンサルティング形態。蓄積されたノウハウに基づいた質のよい 雊型ができていれば, IT コンサルタントのスキルやコンサル ティングのプロセスに余り影響されず, 良い結果になる可能性 が高い。ソリューションの観点からすると, ノウハウとサービ 
スが同じ重みで共存する商品と言える。

以上の定義と実施の方法を踏まえて, 本論文では, IT コン サルティングの構成要素を「IT コンサルタント」, 「コンサル ティング・プロセス」, 「コンサルティング・コンテンツ」とす る（図 4)。IT コンサルティングの結果顧客に提供される価値 は，これらの要素が相互に連携して作り出されるものである。

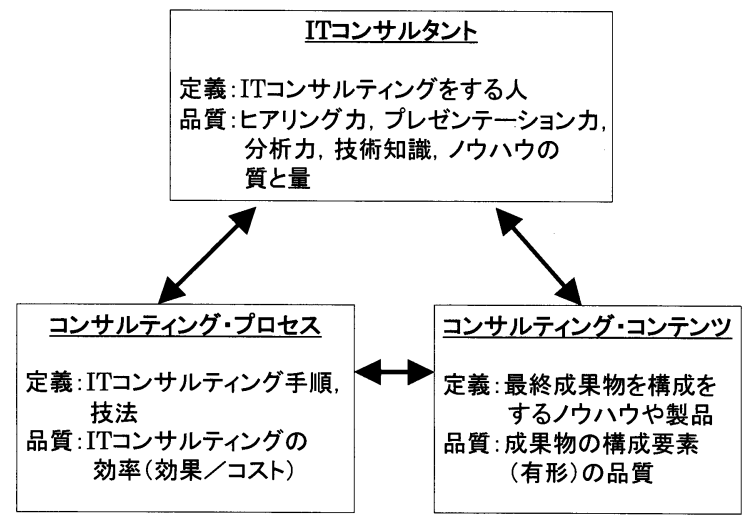

図 4 IT コンサルティングの構成要素

各要素の定義と品質の構成要素は図 4 に示す通りである。

\section{2 IT コンサルティングの品質}

IT コンサルティングの品質を, その構成要素に従って, IT コンサルタントの質, コンサルティング・プロセスの質, コン サルティング・コンテンツの質, を総合したものと考える。以 下に, 各要素の内容を示す。

(1) IT コンサルタントの質

ヒアリングカ, プレゼンテーション力, 分析力, といった スキルと, IT コンサルタントの持つ無形のノウハウ, 知識の 量, 積極性やマナーのよさなどの資質が含まれる。これらは, 持って生まれたものもあるが，教育・訓練により身に付ける ことができる。IT コンサルタントのスキルの高さを示すには,

（独）情報処理推進機構(IPA)が発表している IT スキル標準 (ITSS)の「コンサルタント」の標準が利用できる[9]。ITSS では, プロジェクト管理, リード, コミュニケーション, ネ ゴシエーションという形でスキルが定義されている。具体的 にその高さを定量的に示すのには, MBA や公認会計士など の公的な資格の取得状況や教育受講歴などを使うことになる が，必ずしもそれで測れるとはいえない。また，資質の定量 評価はそれ以上に困難である。

(2) コンサルティング・プロセスの質

IT コンサルティングの進め方が主体である。ここには, 手 順や技法の形で形式知化されたものだけでなく, コミュニケ ーションの取り方, プロジェクトマネジメントの進め方も含 まれる。その高さを評価する方法としてプロセスの成熟度が あげられる。[10]で Humphrey は, その原点ともいうべき内 容を述べている。現実的な評価方法としては，かけたコスト で得られた成果, すなわち, 効率性を測ることがあげられる。

(3) コンサルティング・コンテンツの質

IT コンサルティングにより得られた最終成果物を構成す る有形物の質である。プロセス・コンサルティング, コンテ
ンツ・コンサルティングによりコンテンツの大きさは異なる。 ノウハウを有形化して蓄積したナレッジベースなどもこれに 含まれる。コンテンツは有形であるので, 質の高さは, 通常 のハードウェア，ソフトウェアの質に準じて測ることが可能 と考えられる。

IT コンサルティングの品質は, 上記の 3 要素の組み合わせ となる。最終的な評価は, 顧客がその結果に満足したか否か, で決まる。本論文では，IT コンサルティングを構成する各要 素の実感品質と顧客満足度の関係を分析することで, 顧客満 足度を上げるのに影響する要因を明らかにする。

\section{IT コンサルティング顧客満足度への影響要因分析 \\ 4. 1 IT コンサルティング顧客満足度調查}

\section{(1) 調查の目的}

2. 2 のモデルにおいて, 実感品質が顧客満足度にどう影 響するか，を相関の分析によって明らかにする。同時に，そ の要因についても分析と考察を行い, その上で実感品質をど う制御することによって顧客満足度を上げることができるか, を明らかにする。

\section{(2) 調査対象}

IT ベンダのコンサルティング部門が顧客企業の企画部門, 情報部門に対して，情報システム構築に向けての業務改革支 援, 情報化戦略策定, 情報システム構築計画作成のコンサル ティングを有償で行ったケースを取り上げる。これらは，プ ロセス・コンサルティングに近い形態をとっている。情報シ ステムの設計・構築, 技術支援, 製品導入サービスは含まな い。2003 年 10 月から 2004 年 3 月までに終了した IT コンサ ルティング案件の顧客 48 社を対象に顧客満足度調查を行っ た。その内訳は, 製造業 24 社, 流通業 9 社, 金融業 2 社, 公 共・社会 13 社である。

\section{（3）調查方法}

IT コンサルティングが完了し，顧客が完了を確認した時点 で, 顧客のキーパーソンに対してアンケートを行う。IT コン サルティングを実施した部署のコンサルタントが訪問してロ 頭で質問する方法，CS(Customer Satisfaction)部門がアンケー 卜用紙を郵送して回答を得る方法，のいずれかをとる。

アンケートの内容を表 1 に示す。当該コンサルティング部 門から初めて IT コンサルティングを受けてからの年数 (付合 (年数), 実感品質を問う質問 (14 項目), 本コンサルティン グに対する顧客満足度を聞く。合わせて，11 項目の自由記述 コメントも求める。この回答は必須ではない。

実感品質を問う質問と IT コンサルティングの 3 要素の内 最も関連の梁いものとの対応を示したものが表 2 である。評 価値は 6 段階とする。その意味を表 3 に示す。

(4) 分析方法

アンケートに対して回答が得られたものについて, 次の内 容を分析する。

(1) 実感品質と顧客満足度との相関

顧客満足度と相関の強い実感品質項目，相関の弱い，ある いは無い実感品質項目は何かを調べ，顧客満足度を上げるの 
にどの項目の実感品質を上げればよいかを明らかにする。

(2) 顧客との付合い年数と実感品質・顧客満足の相関の関係 当該部門の IT コンサルティングは, 最初から何年にも渡っ て行われるわけではなく, 1 年の間に何度も IT コンサルティ ングを受けることもない。従って，顧客との付合い年数が 1 年末満の顧客は, 最初の顧客であり, 1 年以上の顧客は, 2 回目以降の顧客である。両者で実感品質項目と顧客満足度の 相関に違いがあるかどうかを調べる。それにより，顧客満足 度を上げるために, 最初の顧客と 2 回目以降の顧客に対する IT コンサルティングの仕方をどう変えるべきかを明らかにす る。

\section{（3）自由記述コメント数と実感品質の関係}

今回の㥶験ではコメントを記入した項目数を測った。自由 記述コメントは必須ではないので, 回答された項目数は, 顧 客の IT コンサルタントへの関心度を含む両者の関係を表し ていると考えられる。コメント数と各項目の実感品質の相関 を調べると同時に，コメントの多い場合と少ないか無い場合 に分けて, 顧客満足度と実感品質の相関の違いを調べる。そ れらにより, 顧客との関係が実感品質と顧客満足度の相関に 与える影響を明らかにする。なお今回コメントの回答項目数 のみを取り上げた理由は，コメント内容や行数が，回答した 時点での感情や直前のイベントに左右されると考えられるか らである。

表 1 IT コンサルティング顧客満足度調查項目

\begin{tabular}{|c|c|c|c|}
\hline \# & \multirow{2}{*}{\multicolumn{2}{|c|}{$\begin{array}{c}\text { 項目 } \\
\text { 付合い年数 }\end{array}$}} & 意味 \\
\hline 1 & & & コンサルティング部門との付合い年数 \\
\hline 2 & \multirow{14}{*}{$\begin{array}{l}\text { 実 } \\
\text { 感 } \\
\text { 品 } \\
\text { 質 } \\
\text { 項 } \\
\text { 目 }\end{array}$} & 目的達成 & プロジェクトの目的を達成できたか \\
\hline 3 & & 成果内容 & 成果物は必要十分な内容だったか \\
\hline 4 & & 成果記述 & 成果物の記述はわかりやすかったか \\
\hline 5 & & 納期遵守 & プロジェクトの納期は守られたか \\
\hline 6 & & 実施期間 & サービス実施期間は適切か \\
\hline 7 & & 訪問日数 & 訪問日数は適切か \\
\hline 8 & & 価格 & サービスの価格は適切か \\
\hline 9 & & 他コスト & サービス期間中の費用は適切か \\
\hline 10 & & 知識 & 業務や IT に関する知識は十分か \\
\hline 11 & & 分析力 & 分析能力, 計画策定能力は十分か \\
\hline 12 & & リード & プロジェクトのリードは適切か \\
\hline 13 & & マナー & コンサルタントのマナーは適切か \\
\hline 14 & & 積極性 & 積極的にプロジェクトに貢献したか \\
\hline 15 & & 傾聴 & 顧客の悩みや意見を引き出していたか \\
\hline 16 & & 満足度 & IT コンサルティングに満足したか \\
\hline
\end{tabular}

表 2 実感品質項目と IT コンサルティング要素の関連

\begin{tabular}{|c|c|c|c|c|c|c|c|c|c|c|c|c|c|c|}
\hline $\begin{array}{l}\text { 要 } \\
\end{array}$ & 目 & 成 & 成 & 納 & 実 & 訪 & 価 & 他 & 知 & 分 & リ & $\nabla$ & 積 & 傾 \\
\hline 素 & 的 & 果 & 果 & 期 & 施 & 問 & 格 & ב & 識 & 析 & 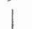 & ナ & 極 & 僡 \\
\hline \# & 達 & 内 & 記 & 遵 & 期 & 日 & & x & & 力 & ド & 1 & 性 & \\
\hline & 成 & 容 & 述 & 守 & 間 & 数 & & $卜$ & & & & & & \\
\hline 1 & & & & & & & & & 0 & 0 & 0 & 0 & 0 & 0 \\
\hline 2 & & & & $\mathrm{O}$ & $\mathrm{O}$ & $\mathrm{O}$ & 0 & 0 & & & & & & \\
\hline 3 & 0 & 0 & 0 & & & & & & & & & & & \\
\hline
\end{tabular}

\section{表 3 回答の評価値と意味}

\begin{tabular}{|c|c|c|c|c|c|c|}
\hline 評価値 & 6 & 5 & 4 & 3 & 2 & 1 \\
\hline 付合い年数 & 15 年一 & $10-15$ 年 & $5-10$ 年 & $3-5$ 年 & 1-3年 & 1 年末満 \\
\hline 実感品質 & 大変 & 満足 & やや & やや & 不満 & 大変 \\
\hline 顧客満足度 & 満足 & & 満足 & 不満 & & 不満 \\
\hline
\end{tabular}

\section{2 分析結果}

48 社に対してアンケートを行い，31 社から回答を得た。内 訳は, 製造業 15 社, 流通業 8 社, 金融業 1 社, 公共・社会 7 社である。また, 回答者の所属部門は, 経営企画 6 名, 情報シ ステム 19 名 (企画担当 14 名, 開発担当 4 名, 運用担当 1 名), ユーザ 1 名，その他 4 名である。

得られた結果を以下に示す。その考察は 5 章で行う。

（1）実感品質を問う質問回答と顧客満足度の相関

各実感品質と顧客満足度の相関を全体，および，2つの観 点で調べた。その結果をまとめたものが表 4 である。

表 4 顧客との関係による実感品質と顧客満足度の相関比較

\begin{tabular}{|l|c|c|c|c|c|}
\hline & \multirow{2}{*}{ 全体 } & \multicolumn{2}{|c|}{ 付合い年数 } & \multicolumn{2}{|c|}{ ニメント数 } \\
\cline { 3 - 6 } & & 1 年未満 & 1 年以上 & 2 以下 & 3 以上 \\
\hline 目的達成 & 0.84 & 0.93 & 0.67 & 0.81 & 0.72 \\
\hline 成果内容 & 0.69 & 0.56 & 0.86 & 0.88 & 0.80 \\
\hline 成果記述 & 0.47 & 0.32 & 0.82 & 0.79 & 0.64 \\
\hline 納期遵守 & 0.47 & 0.35 & 0.78 & 0.71 & 0.66 \\
\hline 実施期間 & 0.81 & 0.93 & 0.62 & 0.40 & 0.82 \\
\hline 訪問日数 & 0.45 & 0.45 & 0.48 & 0.24 & 0.61 \\
\hline 価格 & 0.23 & -0.05 & 0.70 & 0.48 & 0.61 \\
\hline 他コスト & 0.25 & -0.05 & 0.62 & 0.46 & 0.60 \\
\hline 知識 & 0.76 & 0.73 & 0.81 & 0.73 & 0.67 \\
\hline 分析力 & 0.79 & 0.84 & 0.81 & 0.80 & 0.82 \\
\hline リード & 0.63 & 0.55 & 0.77 & 0.64 & 0.79 \\
\hline マナー & 0.21 & 0.27 & 0.15 & 0.19 & 0.52 \\
\hline 積極性 & 0.42 & 0.27 & 0.60 & 0.33 & 0.69 \\
\hline 傾聴 & 0.73 & 0.76 & 0.80 & 0.68 & 0.83 \\
\hline
\end{tabular}

版プ数 : 31

[付合い年数 : 1 年未満(14), 1 年以上(17)； コ朴数: 2 以下(17), 3 以上(14)] 網掛けは有意水準 0.05 で有意な相関

表 4 の 2 列目は各質問項目への回答と顧客満足度の相関を 示している。14 質問項目中 11 項目が有意な相関を持つ。相 関係数が 0.70 以上の強い相関を持つ実感品質項目は, 目的達 成，実施期間，知識，分析力，傾聴，となる。

この結果を見ると, 納期遵守や価格に対する実感品質の顧 客満足度との相関が無いか弱いことになる。通常の IT コンサ ルティングにおいて, 納期遅れや価格が常に問題とされてい る事実があるので，この結果は実態とはかけ離れている。さ らに背景や環境条件を調べる必要がある。

（2）顧客との付合い年数による実感品質と顧客満足度 の相関の違い

実感品質を問う質問回答と顧客満足度の相関を，1 年未満 の顧客群におけるもの, 1 年以上の顧客群におけるものに分 けて調べた。表 4 の 3,4 列目は各質問項目への回答と顧客 満足度の相関を示している。

付合いが 1 年末満の顧客の場合は, 14 質問中 8 項目が有意 な相関を持った。そのうち, 相関係数が 0.70 以上の強い相関 を持つ実感項目は 5 項目である。

一方, 付合いが 1 年以上の顧客の場合は, 14 質問中 13 項 目が有意な相関を持つ。そのうち, 相関係数が 0.70 以上の強 い相関を持つ実感項目は8 項目である。

顧客との付合い年数による実感品質と顧客満足度の相関の 違いを示したのが図 5 である。全体, 1 年末満, 1 年以上の 
顧客別の実感品質と顧客満足の相関を対比させて示している。 1 年以上の顧客と 1 年未満の顧客とでは, 実感品質と顧客満 足度の相関の強弱に違った傾向が見られる。

(1) 1 年未満の顧客では相関が強く, 1 年以上になると相関 が弱くなるもの：目的達成, 実施期間

(2) 1 年末満の顧客では相関が無いか弱いが， 1 年以上にな ると相関が強まるもの：成果内容, 成果記述, 納期遵守, 価 格, コスト,リード, 積極性

(3) 1 年末満, 1 年以上, ともに相関の強いもの: 知識, 分 析力, 傾聴

(4) 1 年未満, 1 年以上, ともに相関の無いもの : マナー 相関の差の大きかった 4 項目 (成果記述, 納期遵守, 価格, 他コスト）について，各々と顧客満足度との相関を図示した (図 6 )。いずれも $\mathrm{X}$ 軸が実感品質項目，Y軸が顧客満足度 である。これらは, 1 年以上の付合いになってから相関の出 て来る項目である。1 年末満の顧客の場合は，価格を除けば 実感品質項目の評価值が高い傾向にあることが見て取れる。

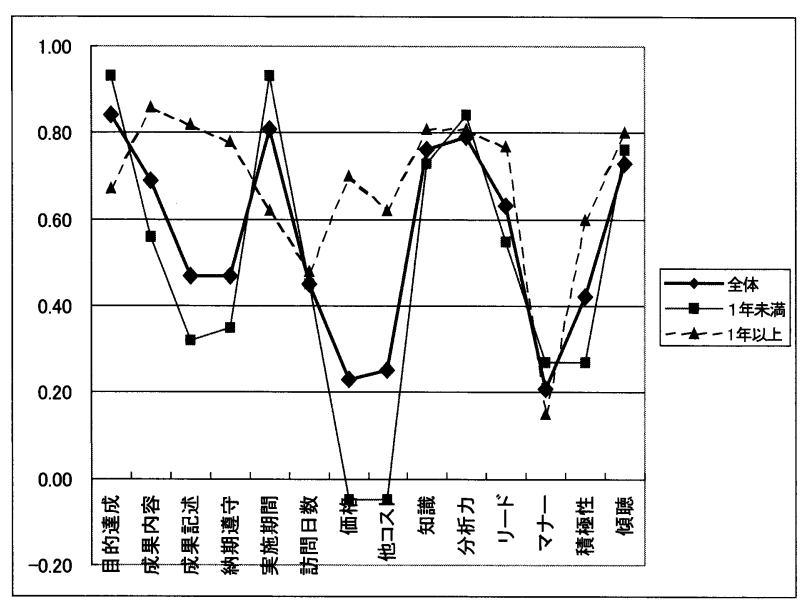

図 5 実感品質と願客満足度の相関（付合い年数別）

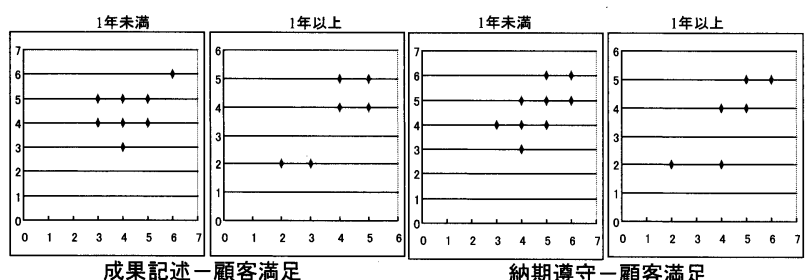

1 年末满

1 年以上

1年未满

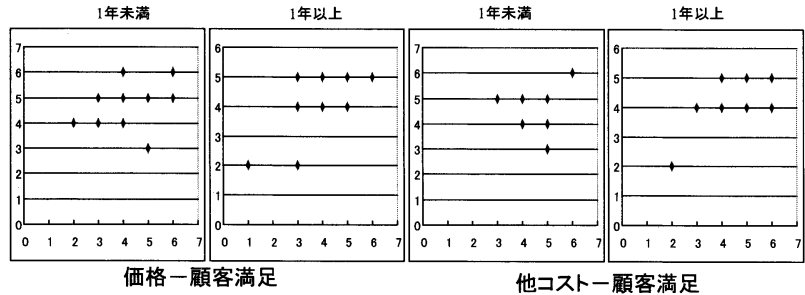

図 6 実感品質と顧客満足度の相関の詳細（付合い年数別）

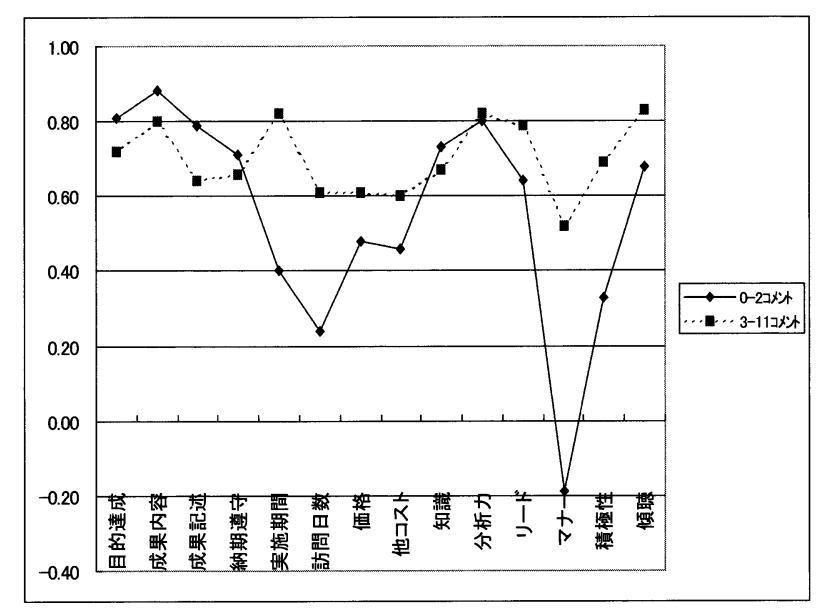

图 7 実感品質と顧客満足度の相関（コメント数別）

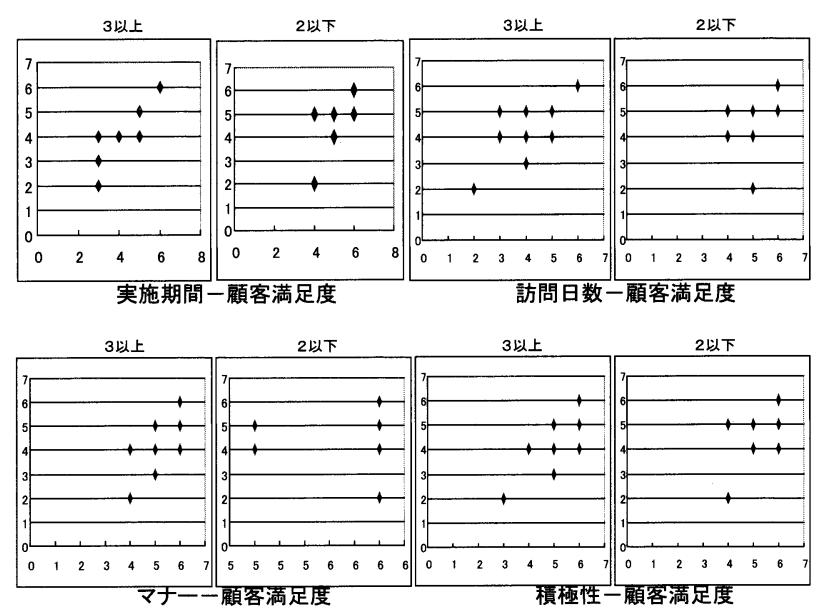

図 8 実感品質と顧客満足度の相関の詳細（コメント数別）

（3）自由記述コメント数と実感品質との関連

自由記述部分のコメントの数と, 実感品質の関係を $2 つ$ つ 方法で調べた。各コメントは，行数によらず， 1 項目を 1 件 とカウントしている。

(1) 各項目の評価値, 顧客満足度とコメント数の相関 付合い年数, 14 項目の実感品質, 顧客満足度の各々とコメ ント数の相関を調べたところ, いずれの項目, 顧客満足度と も, コメント数との有意な相関は無いことが分かった。

(2) コメント数が 2 以下の案件（17 社）と 3 以上 11 以下の 案件（14 社）に分けた場合の, 各々の実質品質項目と顧客満 足度の相関

表 4 の 5，6 列目は各質問項目への回答と顧客満足度の相 関を示している。図 7 はそれを図示したものである。コメン 卜数 3 以上 11 以下の案件は, 全ての実感品質項目と顧客満足 度に相関があり，そのばらつきが少ない傾向にある。一方， コメント数が 2 以下の案件は, 実感品質と顧客満足度の相関 にばらつきが大きく, 訪問日数, マナー, 積極性は, 相関が 無い。

コメント数 3 以上と 2 以下の違いをより詳細に見るために, 相関の差の大きかった 4 項目 (実施期間, 訪問日数, マナ一, 積極性)について, 各々と顧客満足度との相関を図示した（図 8 )。いずれも X 軸が実感品質項目，Y軸が顧客満足度であ 
る。マナーを除けば, コメント数 2 以下の場合, 寒感品質項 目の評価値が高い傾向にあることが見て取れる。

\section{IT コンサルティング顧客満足度要因分析 \\ 5. 1 顧客満足度と実感品質の相関}

顧客に各品質特性に関する評価を求めた場合, その回答は, 「IT コンサルティング自体の品質」と「予測品質」のギャッ プを反映したもの，すなわち，害感品質である。4 章で示し た結果で，IT コンサルティングにおいては，実感品質がその まま顧客満足度に結びつくとは言い切れず, 品質要素によっ て両者の相関に差があり，両者が相関をもつためには条件が あることが分かった。

顧客満足と強い相関を持つ赛感品質の特街は，次の 3 点に なると考えられる。

(1) 顧客が一番不安に思っていることが解消する

初めての顧客にとっての「目的達成」, 「実施期間」がこれ に当たる。その達成には驚きや感動はあまりなく，とりあえ ず安心するといったものであろう。

(2) 顧客自身ができないことができる

分析力, 知識, 傾聴, リードがそれにあたる。期待值は明 確ではないが，専門家でなければ持ち得ない知識，スキルが あれば高くなり, なければ低くなる。

(3) 顧客にとって重要で, 期待值が明確である

「成果の内容」,「成果の記述」,「納期遵守」「価格」がそれ に当たる。例えば価格の場合は, 1 回目の IT コンサルティン グでは期待值が不明確であるが, 2 回目以降には明確になる。 従って，結果を見て良否が判定できるため，顧客満足度との 相関が強くなるのではないか。

以上の分類にあてはまらない実感品質は, 顧客満足度との 相関が無いか弱い。その中には顧客にとって重要とは思われ ないもの, 重要だがその時点では期待值が明確でないものが ある。注目すべきは，重要だが当り前で差別化要因とならな いもの, すなわち衛生要因[11]とされるものである。「マナ 一」は IT コンサルタントなら当然持っているべき資質であり， 衛生要因にあてはまると思われる。

\section{2 実感品質と顧客満足度の相関に影響する要因}

4. 2 の図 7 で示されるように，コメント数が赛感品質と 顧客満足度の相関の強さに影響していることが分かった。

通常, コメントの多くは具体的な指摘事項や不満であると 考えられている。今回は,「特になし」と記入しても 1 件, IT コンサルタントに対する不満を数行記述しても 1 件と計測し た。その結果, コメント数と顧客満足度には有意な相関が見 られなかった。ところが，実感品質と顧客満足度の相関には 影響していた。

この事実の意味を考えてみる。コメントが多いということ は，意見が言い易い関係が築かれている，すなわち，顧客と IT コンサルタントの間のコミュニケーションがよく取られて いると考えてはどうか。その場合に，実感品質が猵客満足度 に影響を与えると考えるのである。これを裏付けるものとし て, 1 年以上の付合いの顧客と 1 年末満の付合いの顧客との
比較結果がある。前者は後者より顧客満足度との相関がある 穾感品質の項目数が多くなっている。

\section{3 高い顧客満足度を得るための要件}

これまで考察してきたことから, IT コンサルティングで高 い顧客満足度を得るための条件をまとめる。

（1）顧客と IT コンサルタントのコミュニケーション 顧客満足度は, IT コンサルティングを行った結果得られる ものであり, IT コンサルティングを行っている間は把握でき ない。従って，2．20図 2 のモデルに従えば，IT コンサル タントができることは, IT コンサルティングの品質を高め, 実感品質を上げることである。その努力が顧客満足度に反映 されるためには, 顧客と IT コンサルタントの間のコミュニケ ーションを良くすること, 双方で意見が交換しやすい関係を 筑くことが必要である。各実感品質項目と顧客満足度に相関 があれば, IT コンサルタントは, その項目の害感品質を上げ ることで満足度を上げることが可能になる。一方, コミュニ ケーションが良ければ, IT コンサルタントは顧客が本当に求 めているものが理解できるようになり, どうすれば結果とし て䫚客満足度向上に結びつくか分かることになる。

（2）初めてIT コンサルティングを受ける顧客への対応 初めての䫚客の場合は, 試行の形で IT コンサルティングを 受ける場合が多い。期間が短いため, 顧客と IT コンサルタン 卜相互の理解ができないまま終わる可能性がある。従って, 2 回目以降の顧客よりもコミュニケーションが取りにくいの で, それを前提に, 各品質要素別の対応をしなければならな い。

試行の場合は，評価すること自体が目的であるため，まず 目的達成が最大の関心事になる。そうでない場合も, 初めて の IT コンサルティングで, 目的が達成されるかどうか不安を 感じるはずである。また, 納期をあらかじめ決めることが難 しいことも多く, 終わって初めて期間が適切かどうかを評価 できることとなる。そこで, 顧客満足度との相関が強い「目 的達成」と「実施期間」に注力する必要がある。また,「分析 力」「知識」「傾聴」といったスキルに関する品質は, 定量的 評価が難しいが, 顧客は, 過去にどこからも IT コンサルティ ングを受けた経験がなければ自社のもつスキルと比較し, 他 社の IT コンサルティングを受けた経験があれば他社の IT コ ンサルタントのスキルと比較して評価するので, 寒感品質と して現れる。プロフェッショナルとして高いスキルあると顧 客が認識すれば, 実感品質が高まり, 顧客満足に結びつく。

（3）IT コンサルティングが 2 回目以降の顧客への対応 顧客とのコミュニケーションをよく取ることは前提である が, さらに顧客満足を高めるための施策を考えていきたい。 2 回目以降は, 過去の実績との比較から, 期待値, すなわち, 予測品質が明確になる。それだけ，品質を高めることが実感 品質に結びつく。この場合は, 顧客満足度と相関の強い実感 品質を高める必要がある。「目的達成」は当然のこととして扱 われるので, 成果物の内容や記述のわかり易さ,「洒格」の実 感品質が重要になる。また, 「実施期間」は「納期遵守」に取 って代わられ, 顧客満足度との相関が強まる。「分析力」,「知 
識」,「傾聴」といったスキルに対する実感品質は相変わらず 顧客満足度と相関が強い。これらは衛生要因とならないので, 常に高める努力が必要である。

6. IT コンサルティング顧客満足度向上策

6. 1 顧客満足度向上プロセスのモデル化

本論文および, [3]に基づいて, IT コンサルティングに限定 せずに, 顧客が商品の情報を得てから実際に購入・使用し, 最 終的に満足を得てリピートオーダーに至るまでのプロセスを モデル化した（図8)。情報収集の段階では, 顧客の商品に対 する感性の鋭さと企業からの情報開示の仕方によって, 予測品 質の決定の仕方に違いが出ることが分かっている[3]。購入し 使用する段階では, 予測品質と商品自体の品質により実感品質 が決まるので, 正しい予測品質が得られていれば, 商品の品質 の高さが赛感品質の高さに結びつくことになる。評価の段階に ついて論じたのが本論文である。赛感品質と顧客満足の相関は, 顧客と企業の相互の関係に影響される。

情報開示, 商品の品質向上, 顧客と企業のコミュニケーショ ンを影響要因と称する。以降の節では, IT コンサルティング の場合を取り上げ, 各影響要因の制御の仕方を述べることとす る。図 8 には対応する節の番号を入れている。

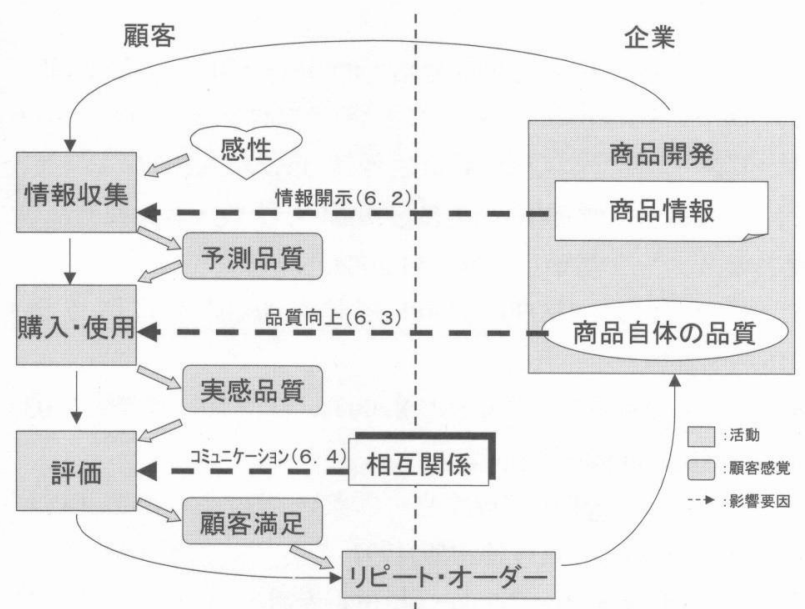

図 8 顧客満足度向上プロセス

\section{2 情報開示による正しい品質予測}

本モデルでは, 企業からの情報開示の顧客の受け止め方を 定量化したものが予測品質であるとしている。また, [3]で は, 十分な情報開示が予測品質を安定させることを示した。 IT コンサルティングという商品においても同じことが言え る。IT コンサルタント, コンサルティング・プロセス, コン サルティング・コンテンツに関する十分な情報を事前に提供 することが必要である。例で示す。

(1) IT コンサルタント : どういったスキル, 経験を持ったコ ンサルタントが担当するのか。

(2) コンサルティング・プロセス : どのような方法論, 手順 により IT コンサルティングを行い, どのような中間成果物, 最終成果物が，いつの時点で得られるのか。

(3) コンサルティング・コンテンツ : 過去にどのような実績 があり, それによってどのようなノウハウが提供できるのか。 いずれも, 対象となる課題解決の技術的な難しさ, リスク要
因も含めて，正しい情報を伝えることが必須である。

6. 3 IT コンサルティング自体の品質向上

3. 1 の表 2 で示したように, 実感品質の各項目は IT コン サルティングの構成要素と関連付けられる。そこで, 構成要 素別に品質向上の方策を考えていく。

(1) IT コンサルタントの品質向上

分析力, リード, 知識, 傾聴, については, IT コンサルタ ントとしてのスキルを高める教育, 訓練により品質向上が図 れる。マナー, 積極性などは, IT コンサルタントの資質に関 わるものであるので, 教育で身につけることは困難である。 ただし, これらは衛生要因であるので, 無いと認められてし まうと大きく満足度を落とす可能性があるので注意が必要で ある。常識的な振る舞いができるようにしておく必要がある。 (2) コンサルティング・プロセスの品質向上

きちんとしたプロセスの定義ができていることが前提で ある。ただし，それが実現できなければ品質は上がらない。 その実現は顧客と IT コンサルタントとの協調で可能になる。 顧客の中にもきちんとした体制を作り, IT コンサルティング の内容に深く関わり，成果に責任を持ってもらえるようにす ることが重要である。

(3) コンサルティング・コンテンツの品質向上

他の要因（IT コンサルタント, コンサルティング・プロセ ス）に影響されずに最終的な成果物の品質を上げるのに最も 有効と思われる方策は, あらかじめ, 品質の良いコンテンツ を用意しておくこと，すなわち，過去の実績から蓄積された ノウハウを活用して最終成果物の㵶型を作っておくことであ る。これは, プロセス・コンサルティングからコンテンツ・ コンサルティングへの移行の推進にもつながる。

6. 4 顧客と企業のコミュニケーションによる実感品質と顧 客満足度の相関強化

本論文の最も重要な論点である。これまでの施策により実 感品質を上げることができたら, 確実に顧客満足に結びつけ る必要がある。そこで重要なのが，顧客との間のコミュニケ ーション，相互に意見が自由に言える関係作りである。例え ば，今回の実験対象となった顧客満足度調查で, IT コンサル タント自身が直接顧客にヒアリングしたケースは 3 社（回答 数の $10 \%$ 未満）に止まった。望ましいのは, 直接顧客と会っ て意見をもらい，良い評価も悪い評価も全て真摰に受け止め る姿勢である。それが, コミュニケーションの良さにつなが る。

\section{7. おわりに}

顧客の求める価值は, 商品というモノ自体から, そこに含 まれるノウハウ, 付帯して提供されるサービスにも広がって いる。商品を購入して使用することによりその価値が得られ たか否かを知るためには, 顧客に尋ねるしかない。それを実 現するのが顧客満足度調査である。しかし, 満足度は結果で あり，それを上げるための方策を得ることはできなかった。 そこで, 本論文では, 雇客満足度を得るまでのプロセスをモ デル化し，影響する要因を明らかにした。 
サービス主体の商品の一つとして, 情報システム構築に関 わる業務改革と情報技術（IT）のコンサルティング（IT コン サルティング) を取り上げ, その構成要素と品質を定義した。 さらに, 実際の IT コンサルティングに対する顧客満足度調査 結果から, 顧客満足度に影響する要因とその影響の条件を分 析し, IT コンサルティングの顧客満足度向上の施策を導き出 した。得られた結果を以下にまとめる。

(1) IT コンサルティングの顧客満足度は, IT コンサルティン グを受けた後の品質要素に対する実感（実感品質）に影響を 受ける。しかし, その影響の度合いは, 各品質要素項目, 顧 客の環境条件により異なる。

(2) 顧客と IT コンサルタントとの間でよいコミュニケーシ ヨンがとられていることにより, IT コンサルティングの赛感 品質と顧客満足度の相関が強くなる。それにより, 実感品質 を高めることが顧客満足につながる可能性が強まる。

(3) IT コンサルティングの顧客満足度を上げるためには, 最 初の顧客であるか, 2 度目以降の顧客であるか, により品質 を高める項目を変えることが必要である。IT コンサルタント の技術力, 分析力などは, 共通して品質を高めるべきもので ある。

本論文では, 最初の段階で, ソリューションという概念で 商品全体を捉えた上で, その構成要素であるサービスの占め る割合の大きい商品である IT コンサルティングを取り上げ, 顧客満足度をいかにして上げていくかについて論じてきた。 その背景には，商品がハードウエア（モノ自体）からノウハ ウやサービスを含めたものになり，近年は後者のウエイトが 高まっている傾向があるからである。今後は, 再度, ソリュ ーションの観点まで視野を広げることで，一般的な商品にも 議論を拡大していきたい。特に, 今回は論じなかったカスタ マー・エクイティ, 寸なわち, バリュー・エクイティ（商品 の効用の客観的評価)，ブランド・エクイティ（商品ブランド に対する主観的評価)，リテンション・エクイティ(ブランド への固執）まで考察する必要がある[12]。

一方, 顧客の心理についても, より梁い考察が必要である。 例えば，顧客は商品購入に対する自分の意志決定に対して一 貫性を保とうとする傾向があるとされている[13]。これを， 顧客満足度について考えてみれば，自分が選択した商品（今 回は IT コンサルティング）を購入した結果に対して, 選択を 正当化する意味も含めて「満足する」傾向が出る，というこ とになる。これが真実か，それを制御する方法はあるか，を 追究していきたい。また，本論文では，顧客満足に至る心理 を，期待（予測品質）と現状の間のギャップを表した「実感 品質」で捉えた。それをより樑めるためには，顧客の心理を マズローの欲求階層モデルと消費行動の関係から捉える[14] など, 新たな視点でモデル化することが考えられる。さらに， 感情が認知に与える影響, 社会の一員としての顧客心理と, 個人としての顧客心理の違いまで追究する必要がある[15]。

多くの企業で, 顧客満足度向上は単なるスローガンに終わ ることが多い。それは, 顧客満足と企業の経営成果 (中長期 的な企業伍值の向上と維持に関わる指標群）の相関が明らか
になっていないためであると思われる。顧客, 株主, 経営者, 従業員が一体となった企業経営における価值創造まで考える 必要がある[16]。例えば, 顧客満足度とリピートオーダーに つながる顧客ロイヤリティの関連分析[17], 顧客满足度と従 業員満足度の関連分析などは, その第一段階となる。今後は, 経営の分野まで踏み込んで研究を梁め, 高い顧客満足の得ら れる商品開発, 提供の方策の追究を行っていきたい。

\section{参考文献}

1 ）小森哲郎,名和高司 : 高業績メーカーは「サービス」を売 る,ダイヤモンド社, PP.30-66,2001.

2) 石田厚子, 湊 淳, 小澤 哲 : 先進的ビジネスモデル／ 商品発想への機械工学分野の発明技法'TRIZ'の適用,感性工 学 (日本感性工学会研究論文集), 4-2,PP.67-76,2004.

3）石田厚子, 湊 淳, 小澤 哲 : 顧客の商品に対する感性 の購入意思決定・品質予測 $の$ 影響分析,感性工学（日本感性 工学会研究論文集)，5-2,2005（掲載決定）。

4）石田厚子 : 顧客の視点による情報システムの総合的満足 度把握とその向上策,「2002 信学技報」,102, [302],PP15-20, 2002. 5）日本電子工業振興協会(JEITA): ソリューションビジネス 普及促進のために『ソリューションアーキテクチャ』を標準 化, 2000,

http://it.jeita.or.jp/jhistory/japanese/committee/SOL/000927.html.

6 ) David H. Maister (高橋俊介監訳) : プロフェッショナル・ サービス・ファーム,東洋経済新報社, PP.79-86,2002.

7 ）日本経営品質賞(JQA)委員会:2004 年度版 日本経営品質 賞アセスメント基準書,PP.45-51,2004.

8 ）岩本威生：ISO9001:2000 解体新書,日本規格協会, PP.67-89,2001.

9）(独)情報処理推進機構(IPA)(2003):「IT スキル標準」, 2003, http://www.ipa.go.jp/jinzai/itss/.

10）Watts S. Humphrey（藤野喜一監訳）: ソフトウエアプロセ ス成熟度の改善,日科技連出版,1991.

11）Karl Albrecht, Ron Zemke（和田正春訳）: サービスマネジ メント,ダイヤモンド社, PP.151-155,2003.

12) Roland T. Rust, Valarie A. Zeithaul, Katherine N. Lemon(近藤 隆雄訳) : カスタマー・エクイティ,ダイヤモンド社, PP.52-66,2001.

13）Robert B. Cialdini（社会行動研究会訳）: 影響力の武器, 誠 信書房, PP.71-135,1991.

14）杉本徹雄 : 「消費者理解のための心理学」, 福村出版, PP.135-138,1997.

15）唐沢銥, 池上知子他 : 社会的認知の心理学,ナカニシャ出 版, PP.152-171,2001.

16）Peter Doyle(恩藏直人監訳) : 価值ベースのマーケティング 戦略論,東洋経済新報社, PP.113-163,2004.

17) W. Earl Sasser, Jr., Thomas O. Jones, 'Why Satisfied Customer Defect', Harvard Business Review, Mar-April, 1995 : 100\%の顧客 満足度を届けるマネジメント,顧客サービス戦略,ダイヤモンド 社,PP.75-114,2000. 